\title{
Fatal Outbreaks of Malignant Catarrhal Fever in 2 Dairy Herds in the Netherlands GD Animal Health
}

\author{
Menno Holzhauer ${ }^{1 *}$, Kees Jan Oosterhuis ${ }^{2}$ and Simon Kimpfler ${ }^{3}$ \\ ${ }^{1}$ Bovine Health Department, GD Animal Health, The Netherlands \\ ${ }^{2}$ Private Practitioner, Crimpenerwaert Dierenartsen, The Netherlands \\ ${ }^{3}$ Department of Pathology, University of Heidelberg, Heidelberg, Germany
}

Submission: March 29, 2018 ; Published: April 09, 2018

*Corresponding author: Menno Holzhauer, Bovine Health Department, GD Animal Health (without service), Deventer, The Netherlands; Email: m.holzhauer@gddeventer.com

\begin{abstract}
Background: Sheep-associated Malignant Catarrhal Fever (SA-MCF) is caused by Ovine Herpes Virus-2. This virus is endemic in most sheep and is the major cause of malignant catarrhal fever worldwide, while last the decennium goats may function as carriers also. Several other viruses are associated with MCF in different other species in the Netherlands. Based on 2 large outbreaks the risks for MCF in case of presence of sheep in dairy herds is discussed.

Results: In one herd 10 dairy cows, 10 of the 21 pregnant (3-6 months of gravidity) youngstock, and 1 non-pregnant heifer and 1 calf all in the same barn died or were euthanized. In the other herd 5 dairy cows, 20 pregnant youngstock and 10 calves died or were euthanized. Based on clinical presentation, post-mortal investigation the diagnosis could be confirmed. Diagnosis and aetio-pathogenesis is discussed.

Conclusion: SA-MCF is able to cause serious economic loss in cattle herds due to high mortality rates. Co-housing of sheep and other ungulates should be avoided especially during lambing season for lack of a protective vaccine. Although lymphoplasmacytic perivascular cuffing and vasculitis in the absence of cavitating lesions are not specific by itself (bona fide) discriminators, they are serious indicative and should be followed by a specific OvHV-2 PCR test.
\end{abstract}

Keywords : Cattle; Sheep; Viral infections; Co-housing; Transmission; Outbreaks

\section{Introduction}

Sheep-associated Malignant Catarrhal Fever (SA-MCF) is caused by Ovine Herpes Virus - 2 (OvHV-2, genus Rhadinovirus, subfamily Gammaherpesvirinae [1]. OvHV-2 is endemic in most flock of sheep and is the major cause of malignant catarrhal fever worldwide [2], while last the decennium goats may function as carriers also [3]. Several other viruses are associated with malignant catarrhal fever (MCF) in different other species. Alcelaphine herpesvirus-1 e.g. causes wildebeest associated MCF in cattle and other species [4].

Although the exact epidemiology of SA-MCF is not elucidated completely [5], it is widely accepted that sheep as healthy carriers of the virus play an essential role in outbreaks in Western-Europe [6,7]. SA-MCF has been diagnosed already for years in the Netherlands (Dinkla, GD, Drachten, The Netherlands, unpublished results) based on clinical signs and pathological examination and is reported regularly. Remarkably, most clinical cases are seen concurrently 5-6 months after of the lambing season. These large outbreaks are in line with outbreaks in other countries like Belgium [8] and countries with high density of sheep like Great Britain [9] and Ireland [10]. Most lambs acquire OvHV-2 at approximately 10 weeks of age under natural flock conditions. Investigation in the USA indicates intense virus shedding between 6 and 9 months of age and the likelihood of a consistent low-level of virus shed by adult sheep throughout the year. Moreover, the increase of SA-MCF in spring shortly after the beginning of lambing season could also reflect other factors than viral shedding levels only, such as climate and seasonal variations in stock densities that could influence exposure [10].

SA-MCF is characterized clinically by fever $\left(>41{ }^{\circ} \mathrm{C}\right)$, in appetence, one or two-sided keratitis and ocular, nasal discharge. Typical histopathological lesions can be seen in lymphoid tissues (lymphadenopathy) and adventitia and walls of medium sized vessels, especially arteries in any organ. These changes are characterized by perivascular accumulation of mainly mononuclear cells (predominantly CD8+ T lymphocytes), fibrinoid necrotizing vasculitis, and proliferation of lymphoblasts in lymph nodes $[11,12]$. Only a small proportion of these 
lymphocytes appear to contain virus, although recent results with virus gene-specific probes indicate that more infected cells may be present than previously thought. It is assumed that tissue damage is caused by the indiscriminate activity of MHCunrestricted cytotoxic T/natural killer cells [2]. The exact mode of transmission of the 0vHV-2 between small ruminants and susceptible cattle is uncertain, but there is convincing evidence that the predominant mode is via nasal secretions [13]. However, descriptions of outbreaks of SA-MCF in cattle on farms without any contact with sheep have also been documented, suggesting aerosol spread [14]. The exact mode of transmission in these cases remains poorly understood. The objective of this paper is to pay attention to both the typical clinical and pathological symptoms, the confirming of the diagnosis and the risks of direct contact with cattle in connection to lambs.

\section{Material and Methods}

The outbreak in the first herd started in May 2012. The herd consisted of 60 dairy cows, 21 pregnant young stock, and 15 calves until 1 year of age and 110 sheep with their lambs in close contact with the heifers. The sheep lambed in the period from December 2011 until May 2012, with on average 2.2lambs/ ewe. The other herd consisted of 55 dairy cows, 31 pregnant youngstock and 25 calves until 1 year of age and over 200 sheep, partly housed at a 20 meters distance from the cattle in an open front shed. The sheep lambed in the period from June until August 2012, with on average 1.9lamb/ewe. One small lamb (3-9 weeks of age) used to climb out of the yard and lie down in the hay just in front of the youngstock where it was sniffed at. From each herd 3 and 4 animals with typical acute clinical symptoms were examined at the pathology unit of the Animal Health Service, Deventer (GD). From both herds 11 and 4 affected animals were tested serologically and virologically for presence of BVDV and BHV-1 at the GD. The PCR test for OvHV-2 on unfixed spleen samples and the serology of 10 other animals (in June and September) in the 1st dairy herd were performed at the Virus Surveillance Unit of Moredun Research Institute in Edinburgh, UK.

\section{Results}

In the $1^{\text {st }}$ herd 10 dairy cows, 10 of the 21 pregnant (3-6 months of gravidity) youngstock, and 1 non-pregnant heifer and 1 calf (born in January 2012) all in the same barn died or were euthanized., Most of the heifers (16/22) and the dairy cows died or were euthanized within a period of 10 days, although the period between the first and the last case extended from May 13Th to August 20Th. Most of the affected dairy cows were housed in another stable at a 15 meters distance from the sheep. But almost all had contact during the non-lactating period while they were pastured at an even closer distance $(1.5 \mathrm{~m})$ to the sheep pastures.

In the $2^{\text {nd }}$ herd, 5 dairy cows, 20 pregnant youngstock and 10 calves (born $>1 / 1 / 12$ ) died or were euthanized. The lambing period was from June until August 2012, while the first heifer died in September 2012 and the last in January 2013.
Clinical signs noted in all affected animals were fever (41.5$42.0^{\circ} \mathrm{C}$ ), severe inflammation of mucous membranes (eye, nose, mouth and vagina), muco-purulent discharges, bilateral keratitis, anorexia, and dehydration.

At necropsy the most significant macroscopic lesions were corneal opacity, mucosal hyperemia, marked dehydration, moderate lung edema, and few content in the gastrointestinal tract. Histopathologically in all examined animals generalized lymphoplasmacytic perivascular cuffing and vasculitis especially in the brain and medulla oblongata and variably in other organs was noted. All serological tests for OvHV-2 were positive.

Blood samples in July of 9 animals (without clinical symptoms) all tested negative. In September these cows also tested negative, except for one equivocal positive result. This dairy cow was during 1.5 month housed in the pen with the heifers before the start of the lambing season and had during summer a short period of transient fever (highest temperature measured was $39.8^{\circ} \mathrm{C}$ that declined the next day to $<39.0^{\circ} \mathrm{C}$ ).

\section{Discussion}

Two large fatal outbreaks of OvHV-2 in dairy herds that had direct contact with lambing sheep were observed. After a short period of illness respectively 22 and 35 animals died or were euthanized because of severe clinical signs related to OvHV2 within a period of 3 months. The reason why in most herds mainly pregnant youngstock were affected, may be related to the distance between the sheep and this group of animals in both herds. Although the incidence of OvHV-2 infections in The Netherlands and Belgium is low, the GD is consulted approximately 5 times a year for OvHV-2 related outbreaks $([15,16])$.

Based on a report from Norway [6] it seems that the prevalence of infection in cattle and swine is influenced neither by age nor the extent of contact with sheep and goats. The incidence in these Dutch herd was remarkably higher: 10 affected heifers out of 21 present in the first and 20 out of 31 in the other herd (16\% in Norway vs. 48 and $65 \%$ in the Dutch herds). Also the dairy cows were kept at close distance to the sheep sheds; cows from the 1st herd walked closely along the shed twice daily. Most likely, the infection pressure in the herd is dependent of the number and age of the newborn lambs, environmental factors (e.g. ventilation) and the distance between sheep and cattle herds. OvHV-2 viral DNA also has been detected in samples from the alimentary, respiratory and urogenital tracts of sheep [17]. In the Netherlands most MCF outbreaks were diagnosed during the summer months. Based on an incubation period after experimental inoculation of cattle of 2-12 weeks [18] a transmission by growing lambs seems to be more likely. And therefore to minimize the risk of OvHV-2 infection in susceptible cattle it seems prudent not to co-house sheep with other ungulates or to deprive lambs from colostrum to prevent transmission during their second month of life and subsequently high virus shedding [19]. 
The cow with the equivocal positive serological result had a short period of slightly increased body temperature. Sporadic reports show that few animals in herds with clinical OvHV-2 associated disease may remain serologically positive without evidence of signs [20].

Despite the lack of these important clinical features, other dispatches of seroconverted yet clinically healthy animals stress that infection is not inevitably leading to overt disease and that the incidence may be higher than assumed $[2,21]$.

SA-MCF is able to cause serious economic loss in cattle herds due to high mortality rates. Co-housing of sheep and other ungulates should be avoided especially during lambing season for lack of a protective vaccine. Although lymphoplasmacytic perivascular cuffing and vasculitis in the absence of cavitating lesions are not by itself specific (bona fide) discriminators, they are indicative and should be followed by a specific OvHV-2 PCR test.

\section{References}

1. Plowright W (1990) Malignant catarrhal fever virus. In: Dinter Z \& Morein B (Eds.), Virus infections of ruminants. Elsevier Sci. Publishers BV, New York, NY, USA, pp.123-150.

2. Russell GC, Stewart JP, Haig DM (2009) Malignant catarrhal fever: a review Vet J 179: 324-335.

3. Li H, Wunschmann A, Keller J, Hall DG, Crawford TB (2003) Caprine Herpesvirus-2-Associated Malignant Catarrhal Fever in White-Tailed Deer (Odocoileus Virginianus) J Vet Diagn Invest 15: 46-49.

4. Pretorius JA, Oosthuizen MC, van Vuuren M (2008) Gammaherpesvirus carrier status of black wildebeest (Connochaetes gnou) in South Africa. J South Afric Vet Ass 79: 136-141.

5. Benetka V, Krametter-Froetscher R, Baumgartner W, Moestl $\mathrm{K}$ (2009) Investigation of the role of Austrian ruminant wildlife in the epidemiology of malignant catarrhal fever viruses. J Wildl Dis 45: 508511.

6. Løken T, Bosman AM, van Vuuren M (2009) Infection with Ovine herpesvirus 2 in Norwegian herds with a history of previous outbreaks of malignant catarrhal fever. J Vet Diagn Invest 21: 257-261.

7. Reid HW, Buxton D, Pow I, Finlayson J (1989) Isolation and characterisation of lymphoblastoid cells from cattle and deer affected with 'sheep-associated' malignant catarrhal fever. Res Vet Sci 47: 9096.

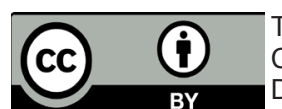

This work is licensed under Creative Commons Attribution 4.0 License DOI: $10.19080 / J D V S .2018 .05 .555672$
8. Pardon B, Maes S, Nollet H, De Bleecker K, Kerkhofs P, et al. (2009) An outbreak of the peracute form of malignant catarrhal fever in Belgian cattle. Vl Diergeneesk Tijdschr 78: 359-364.

9. Holliman A, Daniel R, Twomey DF, Barnett0 J, Scholes S, et al. (2007) Malignant catarrhal fever in cattle in the UK, Vet Rec 161: 494-495.

10. Collery P, Foley A (1996) An outbreak of malignant catarrhal Ireland. Vet Rec 139: 16-17.

11. Nelson DD, Davis WC, Brown WC, Li H, Oaks JL et al. (2010) CD8(+)/ perforin(+)/ WC1(-) gammadelta T cells, not CD8(+) alphabeta T cells, infiltrate vasculitis lesions of American bison (Bison bison) with experimental sheep-associated malignant catarrhal fever. Vet Imm and Immunopath 136: 284-291.

12. Brown CC, Baker DC, Barker IK (2007) Alimentary system. In: Maxie MG (Eds.), Palmer's Pathology of Domestic Animals. ( $5^{\text {th }}$ edn). Elsevier Ltd, Philadelphia, PA, USA, 2: 152-158.

13. Hüssy D, Janett F, Albini S, Stäuber N, Thun R, et al. (2002) Analysis of the pathogenetic basis for shedding and transmission of ovine gamma herpesvirus 2. J Clin Microbiol 40: 4700-4704.

14. Li H, Taus NS, Lewis GS, Kim O, Traul DL, et al. (2004) Shedding of ovine herpesvirus 2 in sheep nasal secretions: the predominant mode for transmission. J Clin Microbiol 42: 5558-5564.

15. Pardon B, Nollet H, Maes S, Deprez P (2008) Malignant catharral fever: a wolf in sheep's clothing. Vl Diergeneesk. Tijdschr 78: 56-61.

16. Van WSL, Knibbe GC (2007) Large outbreak of malignant catarrhal fever in cattle. Tijdschr Diergeneeskd 132: 732-734.

17. Reid HW, Buxton D, Pow I, Finlayson J (1989) Isolation and characterisation of lymphoblastoid cells from cattle and deer affected with sheep-associated malignant catarrhal fever. Res Vet Sci 47: 90-96.

18. Taus NS, Oaks JL, Gailbreath K, Traul, DL, Li H, etal. (2006) Experimental aerosol infection of cattle (Bos taurus) with ovine herpesvirus 2 using nasal secretions from infected sheep. Vet Microb 116: 29-36.

19. Cunha CW, Gailbreath KL, Knowles DP, Schneider DA, White SN, et al. (2012) Ovine herpesvirus 2 infection in American bison: virus and host dynamics in the development of sheep-associated malignant catarrhal fever. Vet Microb 159: 307-319.

20. Taus NS, Montgomery DL, Oaks JL, Crawford TB, Li H, et al. (2007) Intra-nasal inoculation of American bison (Bison bison) with ovine herpesvirus-2 (OvHV-2) reliably reproduces malignant catarrhal fever. Vet Pathol 44: 655-662.

21. Yazici Z, Arslan HH, Gumusova SO, Meral Y, Albayrak H (2006) Occurrence of ovine herpes virus type- 2 infection in sheep and cattle in Samsun Province, Turkey, Dtsch Tierärztl Wochenschr 113: 348-350.

\section{Your next submission with Juniper Publishers will reach you the below assets}

- Quality Editorial service

- Swift Peer Review

- Reprints availability

- E-prints Service

- Manuscript Podcast for convenient understanding

- Global attainment for your research

- Manuscript accessibility in different formats

( Pdf, E-pub, Full Text, Audio)

- Unceasing customer service

Track the below URL for one-step submission https://juniperpublishers.com/online-submission.php 